\title{
How much does parental language behaviour reflect their language beliefs in language maintenance?*
}

\author{
Shanjiang Yu \\ Faculty of Applied Humanities, Auckland University of Technology, \\ New Zealand
}

\begin{abstract}
It has been widely accepted that parental language beliefs play a crucial role in language maintenance. Studies show that Chinese immigrants are not exempted from language shift although they are frequently reported cherishing their language as an important part of their culture. This paper attempts to find out how parental language beliefs reflect their daily language behaviour. Eight recent Chinese migrant families had 60 minutes of conversation recorded each month for one calendar year. Their language use has been analyzed and compared with the information gathered from a home language use questionnaire. Results show that there is a substantial gap between parental language beliefs and their actual language behaviour. Although the parents state they strongly support mother tongue maintenance, within 28 months, the use of mother tongue had dropped significantly and there is very little evidence showing much effort from the parents to prevent this from happening. This could be either because they want their children to keep their first language but do not know how to do this, or, their language beliefs are different from their behaviour. This should raise methodological issues regarding how to interpret parental language beliefs properly in the research area.
\end{abstract}

\section{Introduction}

Language maintenance (LM) refers to "relative language stability in number and distribution of its speakers, its proficient usage by children and adults, and its retention in specific domains" (Baker, 2006, p. 75). It is often, but not only, a concern for minority immigrants because language shift (LS), the opposite process of LM, has been observed to be complete within three generations (Fishman, 1991). Over the past two or three decades, much work has been done at a macro level trying to 
find out the social factors relating to this phenomenon; far less attention has been paid to investigations of people's language use at micro level. It has been widely accepted that parental language beliefs have a crucial role in LS and LM, yet, not much is known about the degree to which parental language practices reflect their language beliefs, particularly when they are interacting with their children. This paper, which is developed from a larger project (Yu, 2005), attempts to address this issue.

\section{Parental language beliefs and their language practice}

People have beliefs in and attitudes to the language they speak and those beliefs and attitudes also influence how people learn and use the language. However, these two terms, beliefs and attitudes, are so closely related that it is not easy to separate them in practice. Therefore, sometimes one of them is used as the cover term (Gibbons \& Ramirez, 2004). In this paper, beliefs is used to cover both beliefs and attitudes. Relevant issues have first been systematically discussed by De Houwer (1999). Despite a paucity of empirical studies, De Houwer has pinpointed some key issues in the area of study. In De Houwer's point of view, parental beliefs form a continuum ranging from negative beliefs, to neutral beliefs and to positive beliefs; further, these beliefs could be either towards a particular language or towards how a language is used in social or family contexts. Following this line of thinking, De Houwer proposed a three-tiered framework to explain the complex relationship between parental beliefs, parental linguistic choice and interaction strategies, and children's language development.

At a social level, the beliefs of the society towards a language or a community group could also influence people's language behaviour in relation to language maintenance and language shift (LMLS). Hostile and suppressive beliefs toward the minority language can result in either greater efforts to maintain it or language assimilation. The Chinese community in New Zealand is a good example in this respect. In her study of LMLS among the New Zealand-born Chinese in the Wellington area, Roberts (1991) found that during periods of adverse discrimination, earlier generations of Chinese people had to keep a low profile, which, at least temporarily, reinforced their daily practice of language maintenance. Yet, Clyne and Kipp's (1999) Australia study found that younger or second generation Chinese reacted to waves of racial discrimination by integrating as quickly as possible into mainstream Australian society, accompanied inevitably by loss of the community language.

However, a question that has often been overlooked is to what degree parental beliefs reflect their actual behaviour. As asserted by Argyris and Schon (1974), 
human behaviour is determined by two different theories of action, espoused theory and theory-in-use. Espoused theory refers to the world view and values on which people believe their behaviour is based, whereas theory-in-use refers to the world view and values that are implied by their behaviour. Interestingly, few people are aware that the theories they use to take action are not often the ones that they explicitly espouse. Even fewer people are aware of the theories they do use. In early bilingual education research, for example, bilingual parents are often found to be using both languages with their children although they claim to follow one-person-one-language strategy (Lanza, 1997; Goodz, 1989). This raises issues about the accuracy and reliability of the findings from traditional LMLS studies that are often based on census-like surveys and self-report data and are mainly concerned with results. The process is often inadequately documented largely due to the methods employed.

At family level, parental beliefs affect parental language behaviour which in turn may greatly influence their children's language use pattern. A typical example is the adoption of the one-person-one-language policy in inter-marriage families where the parents believe that a child could learn two languages naturally if each parent speaks their own mother tongue with the child (Leopold, 1949; Gal, 1979; Meisel, 1990). Important as they are, reports from studies of the effect of parental language beliefs on children's language behaviour are anecdotal and often embedded in general investigations of language maintenance and language shift, thereby leaving many questions unanswered. A particular question worth asking is why minority immigrant languages are typically lost in three generations when people express a strong desire to maintain them, or, in more specific terms: how do parental beliefs reflect their own behaviours? The answer to this question, it is thought, may shed light on both methodological issues as well as some practical implications for migrant parents.

\section{Parental language beliefs and language shift among overseas Chinese}

Studies focusing on language shift of overseas Chinese communities are limited. In the only book length study, which is based on the observation of 58 speakers and 23 hours of recording of the Tyneside Chinese community in the UK, Li (1994) reported that "a rapid inter-generational language shift from Chinese monolinguals to English-dominant bilingualism is currently taking place” (Li, 1994, p. 114), although parents were greatly concerned with maintaining Chinese. In a study by Clyne and Kipp (1999), LS has occurred for $28 \%$ of second-generation Chinese immigrants from Hong Kong and Taiwan while an average of $67 \%$ of them agreed or strongly agreed that their mother tongue should be maintained. In New Zealand, Roberts (1991) study was the first larger scale survey of language use among 
Chinese immigrants in the Wellington area. Like the respondents in Li's (1994) study, Roberts' 51 informants were all local-born Chinese whose children were also born in New Zealand. Results show that "Cantonese was giving ground to English in all aspects ... when most of them would like to see mother tongue maintenance if without too much sacrifice" (Roberts, 1991, p.38). Although all studies concluded that LS is happening to all those Chinese immigrants, little has been said in relation to how this process has started and progressed particularly in relation to the role of parental beliefs.

\section{Why focus on this group?}

New Zealand has seen a rapidly growing number of Chinese immigrants since it made a major change in its immigration policy in 1986. The Chinese population increased from 26,000 in 1986 to about 82,000 in 1996 and this figure went up to 105,000 in 2001 (Statistics New Zealand, 2006). Among the 'new immigrants', those who came under the Skilled Migrant Category (SMC) account for a large proportion. In 05/06 calendar year, for example, out of the total 51,236 immigrant approvals, more than 54\% $(27,539)$ belongs to SMC (Immigration New Zealand, 2007). SMC migrants are different from many of those who come under Investment or Family Reunion Category in that they are all university graduates and/or have special professional skills in addition to their higher English language ability. On the one hand, they seem very aware of the value of their own language and culture; on the other, when confronted with vital competition in education, employment for themselves and their children, they are also in a better position because of their bilingual repertoire. As highly skilled mobile professionals, these SMCs are quite different from their earlier counterparts in late 19th century who were mainly gold-seeking sojourners who were nearly illiterate in both Chinese and English. Thus, it would be interesting to know what is happening to the first language of this group of people in an English-speaking environment. Particularly, we want to know what their language beliefs are and to what degree the parents perform according to their beliefs.

\section{The study}

\section{Selection of subjects}

The participants of the study were selected using a social-network approach. Based on the aims of the project, information was passed out among friends and eight families were selected according to the following criteria: 
1. The children were recent immigrants under or around ten years of age (See Appendix 1);

2. The parents were all well-educated skilled immigrants (See Appendix 2);

3. Mandarin Chinese was the dominant language in the families;

4. With the exception of one child born in New Zealand, the children had not been exposed to English before they came to New Zealand;

The children were divided into two age groups of four children each (Group 1: 8-11 year-olds; Group 2: 5 year-olds) in order to see whether there are age related patterns. Their average time of stay in New Zealand was about 28 months when data collection started. Participant 5 was born in New Zealand but he met all other criteria. He had limited exposure to English in the home as he had been living mainly with his grandparents who knew very little English. Like the other three children in Group 2, he went to a local English medium kindergarten for about two years before he started primary school.

\section{Audiotape recording}

Audiotape recordings, the primary data used in this study, were collected monthly from the participating families. Parents were asked to record their family conversation with their child. It was assumed that parental recording rather than researcher recording could maximize the natural setting and limit possible topic disruption given the volatility of subjects at this general age. Each recording session lasted for one hour and recordings were collected over a period of twelve months. The decision to make monthly recordings over a period of one calendar year was based on the assumption that twelve monthly sessions would generate a reliable sample for the study.

Altogether 96 tapes were collected and labelled for subject and tape number, for example, as S1-T1 or S4-T12. Given that the focus of the research was on everyday language use, only recordings of every other month have been used for analysis for logistical reasons. It is assumed that the recordings of every other month were adequately representative of everyday language as this behaviour is relatively stable within two months' time. Among the 48 tapes selected from each family, four of them were not included for analysis because there was not enough child-parent interaction in two of them, and the other two were recorded in China while one of the children was visiting her grandparents. This left 44 tapes providing material suitable for analysis. This is a relatively large recorded database compared with similar studies. 


\section{Interview}

A questionnaire (See Appendix 3) was designed to collect general information about the family background and daily language behaviour, and at the same time to investigate parental beliefs in relation to language maintenance and language shift. The questionnaire was originally scheduled to be administered immediately upon the completion rather than in the middle of the tape recording phase. It was believed that this arrangement would reduce possible data contamination gathered in the recordings. However, two intervening events led to a delay in presenting the questionnaire. It was finally administered 7 months after the completion of the recording. One of the events was the 11 September 2001 incident in the United States of America and the other was a bill to change New Zealand immigration policy. It seemed likely that more reliable results could be obtained when people had recovered from the shock of the terrorist attack. Interviews were further delayed by a change of the immigration policy. From early 2002 to late 2002, there was a racially-charged debate in the media about both the magnitude and the composition of migration flows of immigrants from Asia especially China and India (Bedford, 2003). One of the major changes proposed was to increase the English language requirement so as to reduce immigrant numbers. As a result many people, especially Asian immigrants whose first language is not English, felt that they were linguistically disadvantaged and not welcome in New Zealand. It seemed likely that this would impact on people's replies to questions related to selfidentification and long term planning (See section III of Appendix 3). Therefore, the use of the questionnaire was postponed until the researcher believed that the parent-respondents would be less emotionally affected by these events.

The questionnaire based interviews were conducted with each parent in each family in a semi-structured manner. All but one interview were carried out faceto-face in the participating families. One questionnaire was administered by mail. In each family, interviews were carried out separately with each parent to avoid possible influence on the opinions of each by the other. Before an interview started, each parent was given a copy of the questionnaire. The researcher then went through all questions with the parent and marked down all the answers on a separate copy. Follow-up questions were asked and key points written down.

\section{Transcription}

The 44 selected tapes were transcribed following the CHAT transcription system (LIDES Coding Manual, 2000) and coded for language and speaker (see below). Transcripts were then checked for accuracy by another fluent Mandarin/English bilingual who was linguistically qualified. Any differences were resolved by 
discussion. Further, if any uncertainty about an English datum existed, then a native, English-speaking language teacher was consulted.

When providing examples, all English contributions are presented in boldface. Anything uttered in Mandarin was converted into Pinyin - the Chinese phonetic system. Apart from these conventions, a free translation is provided for each Chinese utterance in single quotation marks.

\section{Terminological clarification}

To avoid possible confusion with the use of certain terms, the following terms were used in the study as defined here:

Code-switching (CS) is used to refer to a communication strategy of alternate use of two languages in the same conversational turn ( $\mathrm{Li}, 2000)$. It is regarded as a more advanced and more conscious use of one's bilingual resources. Therefore, CS in this study entails both code alternations from one language to another and mixed use of two languages in the same conversational turn.

Language beliefs is used as a cover term in this study to refer to the beliefs and attitudes which speakers of different languages or language varieties have towards each other's languages or towards their own language (Fasold, 1984).

Chinese is used to refer to Mandarin Chinese unless otherwise specified.

\section{Data analysis of language choice}

Studies involving younger bilinguals have used different units of analysis depending on the specific focus. In this study, conversational turn (Coulthard, 1985) is the unit for analysis as it is the major unit in conversation analysis. A conversational turn may take the following forms:

a. One word from either language is involved. For example:

Example 1: S1-T1

132. M. Zhebian shi shenme yisi?

'What does this side mean?'

133. S1 Decrease.

b. A mixed turn consists of elements from both languages:

Example 2: S2-T3

60. F1 Fangle lajiao le?

'Is there chilli?' 
61. S2 Fangle lajiao number three.

'There is chilli'

c. More than one utterance composed of elements from either or both languages involved:

Example 3: S5 - T9

131. S5 I need to sharpen the pencils now. So give me.

132. M3 All are sharp enough. Don't sharp them any more. Dou xiaode ting jiande, buyong zai xiaole, dou tinghao de.

'All are sharp enough, no need to sharpen again, everyone is in good condition.'

In order to establish the language choice pattern of the participants, all the utterances in the conversation were transcribed in their naturally occurring form and coded for language in three sub-language groups: Chinese, English, and codeswitching. If a turn was unambiguously comprehensible as words of a specific language, they were transcribed in that language. All turns were coded for addressee.

\section{Results}

In this section, results regarding language behaviour from the questionnaire are presented and wherever possible contrasted with the results from recordings. Elaborations are provided when information either from recording or questionnaire is available.

\section{Language choice}

Regarding language use, some frequency categories, for example, "most frequently used language", "often", and "seldom", were used in the questionnaire to capture a general picture of the participants' daily language behaviour. These categories have often been used in census and similar studies as important indicators in LM and LS without any quantitative force. It was anticipated that it would be interesting to see how those terms are reflected in the actual behaviour in this study. 


\section{From the questionnaire}

When the parents were asked which language they used most frequently with their children, all the parents chose Mandarin. Only S3's mother reported that she sometimes switched from Chinese to English with her child. S7's mother reported that she and her husband both used their dialect when they got angry.

\section{From the recordings}

From Table 1 we can see that, on average, the use of Mandarin accounts for $75.6 \%$ of the total turns recorded $(\mathrm{n}=9105)$ whereas the use of English and CS is $10.4 \%$ and $14.1 \%$ respectively. This supports claims that Mandarin is the most frequently used language in these families in terms of conversational turns.

However, there is a large discrepancy across the families. In Family 3, for example, while only the mother reported using English sometimes with her son, parental use of English from this family (40.8\%) almost equals that of Chinese (41.8\%) despite the fact that the father did not report any use of English. This highlights the potential discrepancies between language beliefs and action/behaviour. It indicates the need for research to explore better ways to investigate beliefs/ attitudes related issues.

In relation to children's language choice, there are age-related differences. Table 2 shows that the use of English among younger children in Group 2 (from $12.1 \%$ to $34.3 \%$ ) does not vary as much as that of the older children in Group 1 (from $2.8 \%$ to $65.5 \%$ ) although their most frequently used language is Mandarin. S1 and S4 seem to have maximized their use of Chinese with their parents although their English could be assumed to be stronger than that of their younger counterparts based on the number of years they have spent in a local English-

Table 1. Parents' total language choice with children

\begin{tabular}{|c|c|c|c|c|c|c|c|c|}
\hline \multicolumn{2}{|c|}{ Parents of subjects } & \multicolumn{2}{|l|}{ Chinese } & \multicolumn{2}{|l|}{ English } & \multicolumn{2}{|l|}{ Mixed } & \multirow{2}{*}{$\begin{array}{l}\text { Tota } \\
1214\end{array}$} \\
\hline \multirow{4}{*}{ 气̊ } & 1 & 1062 & $87.5 \%$ & 14 & $1.2 \%$ & 138 & $11.4 \%$ & \\
\hline & 2 & 877 & $84.7 \%$ & 49 & $4.7 \%$ & 109 & $10.5 \%$ & 1035 \\
\hline & 3 & 503 & $41.8 \%$ & 491 & $40.8 \%$ & 210 & $17.4 \%$ & 1204 \\
\hline & 4 & 1130 & $92.1 \%$ & 26 & $2.1 \%$ & 71 & $5.8 \%$ & 1227 \\
\hline \multirow{4}{*}{ Õ } & 5 & 1024 & $75.5 \%$ & 164 & $12.1 \%$ & 168 & $12.4 \%$ & 1356 \\
\hline & 6 & 987 & $65.8 \%$ & 134 & $8.9 \%$ & 380 & $25.3 \%$ & 1501 \\
\hline & 7 & 148 & $78.7 \%$ & 15 & $8.0 \%$ & 25 & $13.3 \%$ & 188 \\
\hline & 8 & 1153 & $83.5 \%$ & 52 & $3.8 \%$ & 175 & $12.7 \%$ & 1380 \\
\hline Total & & 6884 & $75.6 \%$ & 945 & $10.4 \%$ & 1276 & $14.1 \%$ & 9105 \\
\hline
\end{tabular}


Table 2. Children's total language choice with parents

\begin{tabular}{|c|c|c|c|c|c|c|c|c|}
\hline Subject & & Chines & & English & & Mixed & & Total \\
\hline \multirow{4}{*}{ 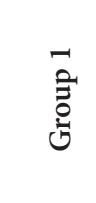 } & S1 & 803 & $74.9 \%$ & 30 & $2.8 \%$ & 239 & $22.3 \%$ & 1072 \\
\hline & S2 & 620 & $69.9 \%$ & 185 & $20.9 \%$ & 82 & $9.2 \%$ & 887 \\
\hline & S3 & 233 & $26.4 \%$ & 578 & $65.5 \%$ & 72 & $8.2 \%$ & 883 \\
\hline & S4 & 934 & $84.1 \%$ & 49 & $4.4 \%$ & 128 & $11.5 \%$ & 1111 \\
\hline \multirow{4}{*}{ 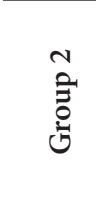 } & S5 & 954 & $73.9 \%$ & 269 & $20.8 \%$ & 68 & $5.3 \%$ & 1291 \\
\hline & S6 & 750 & $52.3 \%$ & 492 & $34.3 \%$ & 192 & $13.4 \%$ & 1434 \\
\hline & S7 & 127 & $70.9 \%$ & 25 & $14.0 \%$ & 27 & $15.0 \%$ & 179 \\
\hline & S8 & 818 & $68.4 \%$ & 144 & $12.1 \%$ & 233 & $19.5 \%$ & 1195 \\
\hline Total & & 5239 & $65.1 \%$ & 1772 & $22.0 \%$ & 1041 & $12.9 \%$ & 8052 \\
\hline
\end{tabular}

speaking school in New Zealand. This seems to suggest that older children are more aware of their language choice while their younger counterparts tend to use their stronger language - English - whenever they want. It must be noted, however, that language competence in the other language is the condition to the older children's addressee orientation.

\section{Are there any rules requiring everyone to speak Chinese at home?}

\section{From the questionnaire}

With reference to the children's language use at home, only one of S1's parents had a rule requiring family members to speak Chinese at home; this parent also said that the rule was often followed by the members of the family. The main reason given by the parent for having such a rule was simply to have a Chinese environment so the child would not lose the mother tongue.

The fact that none of the other parents had this rule shows that the majority of the parents seemed quite relaxed with regard to their children's language use at home or were unaware of the fact that their children's Chinese might be lost over time. Although all of them want their children to maintain their mother tongue, they did not seem to realize that a non-interference policy might be interpreted by the children as indicating that any language is acceptable, thus leaving more opportunities for the children to negotiate their language choice.

The one-parent-one-language approach has been proved to be successful with parents with different native languages and consistency is the key to success. In addition, many studies mention the importance of using the minority language at home between the parents to increase children's exposure to that language 
(Fantini, 1985:30; Döpke, 1992; Baker, 2000:44-45; Romaine, 2000: 192). This seems to be easier for migrant families where both parents speak the same mother tongue. However, the approach is just an ideal macro-structure for language choice. It needs to be realized through micro-structure moves. Therefore, Döpke (1992) concludes that only those parents who can provide enjoyable interaction with a child are likely to succeed in passing on their language.

\section{From the recordings}

In all the transcribed recordings, there are only two occasions when S8's parents attempted to remind S8 to speak Chinese. However, neither of the attempts was a complete success. Here is one example:

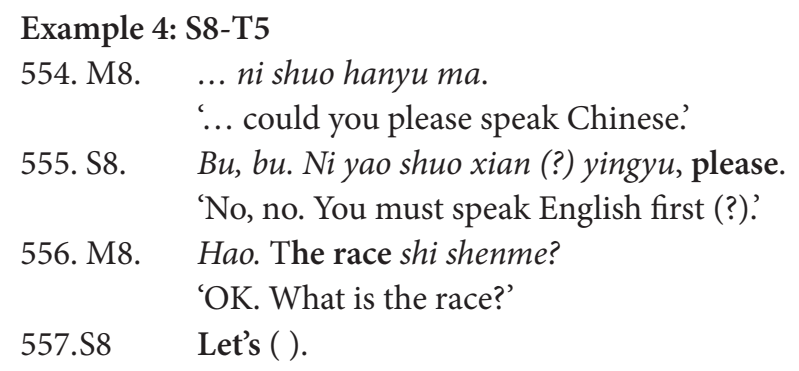

In Turn 554, the mother's suggestion to speak Chinese does have some effect on the child's language choice in his reply although it is a rejection of his mother's suggestion. It is then followed by an English word asking his mother to speak English first. When being further pushed, the boy simply returned to English at the end of this conversation round. This episode tells the child that he wins the code negotiation and his winning could be a clear message that it is acceptable to use English at home and he does not have to speak Chinese if he does not want to.

These results suggest that most of the parents are not acting on their beliefs. For those whose beliefs are genuine, there appears to be a lack of understanding of the importance of family language planning and the parental role as the major input source of their mother tongue. Younger children of migrants are actually learning a second language when it is called mother tongue maintenance. When this occurs, language maintenance is perhaps not an accurate term for these younger immigrants because they do not have much to maintain if they have not received much formal education prior to immigration. If language maintenance refers to a much higher level of skills in the language as is often implied in the literature, then it requires careful planning and serious investment at both family and social level. 
Have you ever felt that your child is using too much English with you?

\section{From the questionnaire}

When asked whether they had ever felt that their child was using too much English, both S7's and S8's parents responded with "Yes" while parents of S1, S4, S5 and S6 chose negative answers. In Family 2 and 3, the parents did not make the same choice. When parents who chose "Yes" were prompted with "What will you do when this happens", the answer was either to remind their child to speak Chinese or simply keep on using Chinese.

\section{From the recording}

From Table 2, we can see that English turns made by S7 and S8 account for 14.0\% and $12.1 \%$ respectively. These figures, although higher than S1's $2.8 \%$ and S4's $4.4 \%$, are much lower than that of the others, which range from S3's $65.5 \%$ to S5's $20.8 \%$. In other words, $12.1 \%$ of English use is too much for Family 8 whereas $65.5 \%$ is not too much for Family 3. This means the belief that the child is using too much English is rather subjective depending on individual circumstances. When S3 was using $65.5 \%$ of English at home, his parents encouraged him to use it more instead of stopping him. Informal conversation with the S3's parents reveals that they were worried about the child's learning of English and were trying to help their son with his oral English. There seemed to be some consensus reached in the family regarding the use of English. On one occasion, for example, when the father suggested using English in the middle of a card game, the whole family immediately switched to English for 126 conversational turns. This shows that, in some families, priority has been given to improve English rather than to maintain Chinese.

\section{Have you ever stopped your child using English and asked them to use Chinese?}

\section{From the questionnaire}

All parents from Family 3, 4, 5 chose "No" for this question. For the other families, there is one parent from each home chose "Yes" while his/her spouse chose "No". 


\section{From the recording}

As is shown in 4.2, there are only two instances recorded from Family 8 when the parents were trying to stop S8 using English. Therefore, there is a big gap between beliefs and actions at least with one of the parents from Family 1, 2, 6, and 7.

\section{How frequently do you speak English with your child?}

\section{From the questionnaire}

For this question, both parents in Family 1, 5 and 6 chose "Rarely". While there is one parent from Family 3 and 4 who chose "Sometimes", their spouses chose "Always" and "Often". S2's parents did not agree with each other by choosing "Sometimes" and "Rarely" respectively for this question.

\section{From the recording}

Table 1 shows that, on top of code-switched turns, English turns made by the parents in Family 1, 5, and 6 are 1.2\%, 12.1\%, and 8.9\% respectively. These would be 'rare use' according to their replies to the questionnaire. However, English turns used by parents in Family 3 and 4 are up to $40.8 \%$ and $2.1 \%$. By any means, Family 3's use of English could hardly be called "Sometimes" as was rated in the questionnaire by one of S3" parents if $12.1 \%$ is "Rare use" for Family 5. Similarly, Family 4's $2.1 \%$ seems better regarded as "Rare use" rather than "Sometimes" or "Always" as was chosen in the questionnaire by the parents. Compared with the data from recordings, therefore, it seems that some parents have over-reported their use of English while others have under-reported their use for this question.

\section{How often do you teach your child Chinese?}

\section{From the questionnaire}

Parents from all families except Family 3 claimed that they have been teaching their children Chinese regularly. This could happen daily $(n=2)$, weekly $(n=7)$, sometimes $(n=4)$ or monthly $(n=1)$. Yet, when prompted with questions such as how they taught, the most common answer was "to provide Chinese equivalents or verbal corrections during conversation". 


\section{From the recording}

Unfortunately, only S1 was recorded learning Chinese on one occasion and there was limited evidence of providing Chinese equivalents and verbal corrections throughout the 44 tapes. On the contrary, parents were frequently recorded providing English equivalents. The lower recorded evidence may be because some parents did not choose to record their Mandarin teaching session. Still, it seems that the children were getting more help with their English than with Chinese. This indicates that improving English has taken priority over maintaining Mandarin in these families.

\section{Discussion and conclusion}

According to Baker (2006), language shift often means "a reduction in the number of speakers of a language, a decreasing saturation of language speakers in the population, a loss in language proficiency, or a decreasing use of that language in different domains" (p. 75). Within an average of 28 months' arrival in New Zealand, it appears that monolingual first language utterance (MFLU) in the participating families has dropped rapidly to a level that may indicate a threshold in language shift (Smith, 2006).

Moreover, results show that parental language behaviour does not always reflect their beliefs. Often, there is a substantial gap between the two. Parents tend to over-report behaviours relating to maintaining their mother tongue but underreport those relating to their use of English.

In terms of language choice, age does seem to play a role in language choice in that 5-year-old children tend to be less aware of the needs of their addressee whereas their older counterparts (8-11 years old) are more capable of accommodating their addressee's language needs. A condition for this to happen is that the children must be competent enough in both languages. This seems to suggest that although two-year-old children could be addressee orientated (Lanza, 1997; Deuchar \& Quay, 2000), how this ability is applied in later age depends on their language competence as well as many contextual factors. When they grow older, they can choose not to speak a particular language because of identity or embarrassment. This result raises an issue relating to the threshold theory proposed in Smith (2006) that one may choose not to use the other language in certain contexts therefore sometimes giving a misleading impression about their ability in the other language.

The core values emphasised in Smolicz (1981) did not seem to be evident in the language practices of this particular community group in relation to LM. Like 
informants in some earlier studies, the parents in this study also regard their L1 and their culture as core values. However, strong parental language beliefs have not been translated into more time and effort invested in their children's bilingual education. Rather, the core values were found to have been overridden by the market values of the mainstream language, English.

This should not be surprising at all considering that maintaining a minority migrant language is extremely challenging because it is not only 'emotionally demanding, but also those demands are often invisible and change over time (Okita, 2002). The parents know that English has a much higher marketplace value than Mandarin Chinese has in an English-speaking country. In New Zealand, it is widely known and repeatedly reported that inadequate English language ability, non-recognition of their qualifications and lack of work experience are the biggest problems for new immigrants with a non-native English-speaking background (Henderson, 2003: 156; Boyer, 1996:66). They know exactly how seriously they have been disadvantaged by their inadequate English language proficiency. For those immigrants who are looking for a better life in a different country, the priority for the whole family is to improve their skills in the mainstream language therefore neglecting to maintain their mother tongue.

The results from this study seem to support Edwards' (2002) claim that minority language maintenance is ultimately a 'forlorn hope'. If we cannot stop LS from happening in the first generation families where both parents are native speakers, there will inevitably be less hope with future generations even if language maintenance does become a priority. It is human nature to miss what is lost. This partially explains why future generations tend to put more value on their ethnic language and ethnic identity than their first generation counterparts do (Sachdev, Bourhis, Phang, and D'Eye, 1987). The key question is still "whether the desire is also the reality" (Edwards, 2002:30), be it language maintenance for minority immigrants or bilingual education in general. For some immigrants, particularly those who have internationally recognised skills, L1 maintenance tends to be regarded first as an economic investment rather than as a means of keeping their ethnic identity. Therefore, language maintenance is a desire that often ends up with language shift for majority of minority immigrants.

Nonetheless, there are steps that can be taken to assist those who do want to maintain their L1. First, belief alone is not enough. Daily efforts are vital. Second, it is important to encourage use of mother tongue as the default language for the family domain. Third, in addition to the quantity of mother tongue input, it is also important to think of ways to increase the quality of the input. The most difficult part for parents is to create an environment in which the child can have a sense of intimacy and closeness in the family, so that motivation to communicate in L1 is emotionally relevant and natural. In this respect we should recall Tannenbaum 
and Howie's (2002) study which claimed that “...family relations play a significant role in language maintenance in immigrant children" (p.420).

Given the small proportion of Chinese ethnics in the New Zealand population generally, it would be too optimistic to expect much promotion of Mandarin at government level. Although foreign languages study has been proposed as a separate subject area in the secondary curriculum, it is still hard to see how much it could benefit LM among Chinese immigrants. Unfortunately, this is a situation faced by most minority languages. The task of maintaining one's ethnic language has been and will remain largely a community and family responsibility.

\section{References}

Argyris, C. \& Schon, D. (1974). Theory into practice. San Francisco: Jossey Bass.

Baker, C. (2000). A Parents' and Teacher's Guide To Bilingualism (2nd edition). Clevedon: Multilingual Matters.

Baker, C. (2006). Foundations of bilingual education and bilingualism. (4th edition). Sydney: Multilingual Matters.

Bedford, R. (2003). New Zealand: The Politicization of Immigration. Retrieved on 12 June 2008 from http://www.migrationinformation.org/profiles/display.cfm?id=86.

Boyer, T. (1996). Problems in Paradise: Taiwanese immigrants to Auckland, New Zealand. Asian Pacific Viewpoint 37(1), 59-79;

Clyne, M. (1982). Multilingual Australia. Melbourne: River Seine Publication.

Clyne, M. \& Kipp, S. (1999). Pluricentric languages in an immigrant context: Spanish, Arabic and Chinese. Berlin: Mouton de Gruyter.

Coulthard, M. (1985). An Introduction to Discourse Analysis (2nd edition). London: Longman.

De Houwer, A. (1999). Environmental factors in early bilingual development: The role of parental attitudes. In G. Extra \& L. Verhoeven (Eds.), Bilingualism and migration (pp. 75-95). Berlin/New York: Mouton de Gruyter.

Deuchar, M. \& Quay, S. (2000). Bilingual acquisition: Theoretical implications of a case study. Oxford: Oxford University Press.

Döpke, S. (1992). One Parent, One Language. An Interactional Approach. Amsterdam: John Benjamins.

Edwards, J. (2002). Forlorn hope? In W. Li, J-M. Dewaele \& A. Housen (eds.), Opportunities and challenges of Bilingualism (pp.25-44). Berlin: Mouton de Gruyter.

Fantini, A. E. (1985). Language Acquisition of a Bilingual Child. Clevedon: Mutilingual Matters.

Fasold, R. (1984). The Sociolinguistics of Society. Oxford: Basil Blackwell.

Fishman, J. A. (1991). Reversing language shift. Clevedon: Multilingual Matters.

Gal, S. (1979). Language shift: Social determinants of linguistic change in bilingual Austria. New York: Academic Press.

Gibbons, J. \& Ramirez, E. (2004). Maintaining a Minority Language. A case study of Hispanic teenagers. Clevedon: Multilingual Matters. 
Goodz, N. S. (1989). Parental language mixing in bilingual families. Infant Mental Health Journal, 10: 25-43.

Henderson, A. (2003). Untapped talents: The employment and settlement experiences of skilled Chinese in New Zealand. In M. Ip (Ed.), Unfolding history, evolving identity: The Chinese in New Zealand (pp. 141-64). Auckland: Auckland University Press.

Lanza, E. (1997). Language mixing in infant bilingualism: A sociolinguistic perspective. Oxford: Oxford University Press.

Leopold, W.F. (1939-1949). Speech Development of a Bilingual Child. A Linguist's Record (4 Volumes). Evanston, IL: Northwestern University Press.

Li, W. (1994). Three generations, two languages, one family: Language choice and language shift in a Chinese community in Britain. Clevedon: Multilingual Matters.

Li, W. (ed.) (2000). The Bilingualism Reader.

LIDES Coding Manual. (2000). Retrieved April 2002 from http://childes.psy.cmu.edu/

Meisel, J. M. (1990). Early differentiation of language in bilingual children. In K. Hyltenstam \& L. Obler (Eds.), Bilingualism across the lifespan: Aspect of acquisition, maturity, and loss (pp. 13-40). Cambridge: Cambridge University Press.

Immigration New Zealand: (2007). Retrieved March. 16, 2007. from http://www.immigration. govt.nz/

Okita, T. (2002). Invisible Work: Bilingualism, language choice, and childrearing in intermarried families. Amsterdam/Philadelphia: John Benjamins Publishing Company.

Roberts, M. (1991). The New Zealand-born Chinese community of Wellington: Aspects of language maintenance and shift. In J. Holmes \& R. Harlow (Eds.), Threads in the New Zealand tapestry of language (pp.31-70). Auckland: Linguistic Society of New Zealand.

Romaine, S. (2000). Bilingualism (2nd edition). Oxford: Basil Blackwell.

Sachdev, I., Bourhis, R., Phang, S., \& D'Eye, J. (1987). Language attitudes and vitality perceptions: intergenerational effects among Chinese Canadian communities. Journal of Language and Social Psychology, 6 (3 \& 4), 287-307.

Smith, D. J. (2006). Thresholds leading to shift: Spanish/English code-switching and convergence in Georgia, U.S.A. International Journal of Bilingualism, 2, 207-241.

Smolicz, J. J. (1981) Core values and cultural identity. Ethnic and Racial Studies, 4, 75-90.

Statistics New Zealand. (2006). Census 2001: Asian People 2001.127-155.

Tannenbaum, M., \& Howie, P. (2002). The association between language maintenance and family relations: Chinese immigrant children in Australia. Journal of Multilingual and Multicultural Development, 5, 408-424.

Yu. S. (2005). Family factors in bilingual children's code-switching and language maintenance: A New Zealand case study. PhD Thesis submitted to Auckland University of Technology, Auckland, New Zealand. 


\section{Appendix 1: General characteristics of the subject-group}

\begin{tabular}{|c|c|c|c|c|c|c|}
\hline \multicolumn{2}{|c|}{ Subjects (S) } & Sex & $\begin{array}{l}\text { Age } \\
(\mathrm{Y} ; \mathrm{M})\end{array}$ & $\begin{array}{l}\text { Length of stay } \\
\text { in NZ }(Y ; M)\end{array}$ & $\begin{array}{l}\text { Education } \\
\text { completed } \\
\text { in China }(\mathrm{Y})^{\star}\end{array}$ & $\begin{array}{l}\text { Living with } \\
\text { grandparent }\end{array}$ \\
\hline \multirow{4}{*}{$\overrightarrow{0}$} & S1 & Male & $10 ; 9$ & $3 ; 4$ & Y2 & No \\
\hline & S2 & Female & $9 ; 3$ & $1 ; 6$ & Y2 & No / Yes \\
\hline & S3 & Male & $9 ; 1$ & $1 ; 9$ & Y1 & No \\
\hline & S4 & Female & $8 ; 8$ & $2 ; 9$ & Nil & No \\
\hline \multirow{4}{*}{ 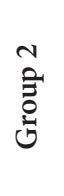 } & S5 & Male & $5 ; 4$ & $5 ; 4$ & $\mathrm{~N} / \mathrm{A}^{* * *}$ & Yes \\
\hline & S6 & Female & $5 ; 1$ & $2 ; 3$ & Nil & Yes \\
\hline & S7 & Female & $5 ; 10$ & $3 ; 1$ & Nil & No \\
\hline & S8 & Male & $5 ; 1$ & $1 ; 9$ & Nil & No \\
\hline
\end{tabular}

${ }^{*} \mathrm{Y}$ refers to the grade attended in primary school (e.g. Y2=year 2)

** S2's grandparents came in the ninth month of the data collection.

$* * *$ S5 was born in New Zealand

\section{Appendix 2: Parental characteristics of the subjects}

\begin{tabular}{|c|c|c|c|c|c|}
\hline \multicolumn{2}{|c|}{$\begin{array}{l}\text { Subject-Parent Links } \\
(\mathrm{F} / \mathrm{M})^{*}\end{array}$} & \multirow{2}{*}{$\begin{array}{l}\text { Highest degree } \\
\text { Bachelor }\end{array}$} & \multirow{2}{*}{$\begin{array}{l}\text { Major } \\
\text { Electronics }\end{array}$} & \multirow{2}{*}{$\begin{array}{l}\text { IELTS } \\
\text { Results }^{* *} \\
\mathrm{~N}\end{array}$} & \multirow{2}{*}{$\begin{array}{l}\text { Length of stay } \\
\text { in NZ }(\mathrm{Y} ; \mathrm{M})^{*} \\
1 ; 1\end{array}$} \\
\hline S1 & $\mathrm{F}$ & & & & \\
\hline & M & Bachelor & Agriculture & $\mathrm{Y}$ & $3 ; 4$ \\
\hline \multirow[t]{2}{*}{ S2 } & $\mathrm{F}$ & Bachelor & English & $\mathrm{Y}$ & $1 ; 11$ \\
\hline & M & Bachelor & Engineer & $\mathrm{Y}$ & $1 ; 11$ \\
\hline \multirow[t]{2}{*}{ S3 } & $\mathrm{F}$ & Master & Computer & $\mathrm{Y}$ & $1 ; 5$ \\
\hline & M & Bachelor & Architecture & $\mathrm{Y}$ & $1 ; 5$ \\
\hline \multirow[t]{2}{*}{ S4 } & $\mathrm{F}$ & Master & Biology & $\mathrm{Y}$ & $5 ; 3$ \\
\hline & M & Bachelor & Biology & $\mathrm{N}$ & $5 ; 3$ \\
\hline \multirow[t]{2}{*}{ S5 } & $\mathrm{F}$ & Master & English & $\mathrm{Y}$ & $12 ; 7$ \\
\hline & M & Bachelor & English & $\mathrm{Y}$ & $11 ; 5$ \\
\hline \multirow[t]{2}{*}{ S6 } & $\mathrm{F}$ & Bachelor & Computer & $\mathrm{Y}$ & $1 ; 11$ \\
\hline & M & Master & English & $\mathrm{Y}$ & $1 ; 11$ \\
\hline \multirow[t]{2}{*}{ S7 } & $\mathrm{F}$ & Master & English & $\mathrm{Y}$ & $2 ; 0$ \\
\hline & M & Bachelor & English & $\mathrm{Y}$ & $2 ; 0$ \\
\hline \multirow[t]{2}{*}{ S8 } & $\mathrm{F}$ & Master & English & $\mathrm{Y}$ & $1 ; 9$ \\
\hline & M & Master & English & $\mathrm{Y}$ & $1 ; 9$ \\
\hline
\end{tabular}


${ }^{*} \mathrm{~F}=$ father; $\mathrm{M}=$ mother;

${ }^{* *}=$ This refers to their IELTS (International English Language Testing Services) results required by New Zealand Immigration Office. Y means the parent has passed IELTS at least at Band $5 . \mathrm{N}$ means the parent does not have the evidence of passing IELTS at least at Band 5 which is the minimum requirement for English Language.

\section{Appendix 3: Questionnaire for Language Use at Home}

I. Family background

$1.1 \quad$ Sex: $\quad$ Male $\square$ Female $\square$

$1.2 \quad$ Age: $\quad 21-29 \quad \square \quad 31-39 \quad \square \quad 41-49$

1.3 What was your occupation in China?

1.4 What is the highest level of education you have reached?

Father Mother

Diploma

Bachelor

Master

Doctor

1.5 How long have you had lived in New Zealand? years months

1.6 Do you plan to stay in New Zealand for the next five years? Yes $\square$ No $\square$ Uncertain

1.7 Do you consider New Zealand 'home'? Yes $\square$ No $\square$ Uncertain

1.8 How well could you speak English when you arrived in New Zealand (circle)? Verywell Quite well Fairly Poor Very poor

1.9 Which language / dialect do you use with your spouse most of the time at home? Mandarin $\square$ English $\square$ Other

1.10 What language /dialect do you use with your children most of the time at home? Mandarin $\square$ English $\square$ Other

II. The child's language use at home

2.1 How old was the child when s/he first arrived in New Zealand? years months

2.2 How long has the child been in New Zealand now? years months

$2.2 \mathrm{i}$ Is there a rule that you can speak only Chinese in your home?

Yes

No $\square$ (go to 2.3) 
ii If yes, to what extent do people always follow it? always often half and not very never half often

Why?

2.2 Have you ever felt that your child is using too much English with you at home? Yes $\square$ No $\square$ Uncertain

If yes, what do you usually do when you feel your child is using too much English? 1.

2.

3.

2.3 Have you ever stopped your child using English and asked them to use Chinese? Yes $\square$ No $\square$

If yes, does the child usually do as you say?

$$
\text { Yes } \square \text { No } \square
$$

2.4 How often do you use English with your child (circle)?
Always
Most of time
Sometimes
Rarely
Never

2.5 In which language skill is the child stronger?:

$\begin{array}{llll}\text { Listening } & \text { Mandarin } & \text { English } & \text { Other } \\ \text { Speaking } & - & & \\ \text { Reading } & & & \\ \text { Writing } & & & \end{array}$

2.5 When the child is at home, what language s/he would use in these situations?

$\begin{array}{lllll}\text { Always } & \text { Mainly } & \text { Both } & \text { Mainly } & \text { Always } \\ \text { Mandarin } & \text { Mandarin } & \text { Equally } & \text { English } & \text { English }\end{array}$

Asking for a favor

Expressing thanks

Apologizing to someone

Telling a joke

Talking to themselves

Getting angry

Greeting

Saying goodbye

$\begin{array}{ll}\square & \square \\ \square & \square \\ \square & \square \\ \square & \square \\ \square & \square \\ \square & \square \\ \square & \square \\ \square & \square\end{array}$

2.6 If any of the following people live in the same house,

i. What language does the child use when speaking to the following relatives?

ii. What language does the relative use when speaking to the child ?

\begin{tabular}{|c|c|c|c|c|}
\hline & & $\begin{array}{l}\text { Always } \\
\text { Chinese }\end{array}$ & $\begin{array}{l}\text { Both } \\
\text { equally }\end{array}$ & $\begin{array}{l}\text { Always } \\
\text { English }\end{array}$ \\
\hline \multirow[t]{2}{*}{ Grandparents } & i the child uses to them & $\square$ & $\square$ & $\square$ \\
\hline & ii they use to the child & $\square$ & $\square$ & $\square$ \\
\hline \multirow[t]{2}{*}{ Aunties/uncles } & i the child uses to them & $\square$ & $\square$ & L \\
\hline & ii they use to the child & $\square$ & $\square$ & $\square$ \\
\hline
\end{tabular}


2.7 i. Apart from the people the child lives with, how often does the child mix with other Chinese-speaking people?
Everyday
Once a week
at least
at least
Once a mon
Every 3 months
Less often

ii. What language / dialect does the child usually use with his/her Chinese friends
Always
Mostly
both
Mostly
Always
Mandarin Chinese equally English English

2.8 How often does the child do the following in Mandarin?
Every day Once a week at least at least
Less often
Read Chinese story books

$\begin{array}{ll}\square & \square \\ \square & \square \\ \square & \square \\ \square & \square\end{array}$
Listen to Chinese radio
Watch Chinese TV/audio tapes
Watch Chinese videos
Go to Chinese websites
or never

2.9 i. Do you think that your child is better at expressing some ideas or feelings in English than in Chinese?

Yes $\square$

$\square$ No (go to ii)

If yes, what kind of things?

ii. Do you think that the child is better at expressing some ideas or feelings in Chinese than in English?

Yes $\square$

No $\square \quad$ (go to 3.1)

If yes, what kind of things?

\section{Language attitudes and language maintenance}

3.1 Would you describe yourself mainly as a:
Chinese
Mainly
Half
Mainly
New Zealander
Chinese and half New Zealander

3.2 Do you think a person has to be able to speak Chinese to be a real Chinese?

Yes

Uncertain

3.3 Do you think the Chinese language is in danger of being lost in New Zealand?

Definitely Maybe yes Uncertain Maybe not Not at all

Why?

3.4 i. Do you want your child to keep Chinese?

Yes $\square$

No $\square \quad$ (go to 4.2 ) 
ii. If yes, how important do you think Chinese is to your child?

Extremely very Important Not very Not important important important important at all

iii. Please give reasons for maintaining Chinese with your child:

i.

ii.

iii.

3.5 Do you worry that your children may lose their Mandarin?

Yes $\square$ No $\square$ Uncertain

3.6 Which language skills (in Mandarin) do you think is most important for your children?

Listening $\square \quad$ Speaking $\square \quad$ Reading $\square \quad$ Writing

3.7 Do you try to teach your child Mandarin in the following aspect:

Listening $\square \quad$ Speaking $\square \quad$ reading $\square \quad$ writing

3.8 How frequently do you do this?

Everyday Every week Twice a month Once a month Seldom

3.9 Is the child attending or has the child attended any class learning Mandarin?

Yes $\square$

No $\square \quad$ (go to ii)

b) If yes, for how many years?

years

months.

c) Are you planning to do so in the next two years?

Yes $\square \quad$ No $\square$ Uncertain

3.9 How important do you think you are in keeping your child using Chinese at home?

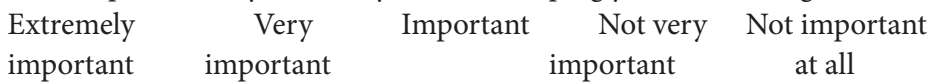

important important important at all 